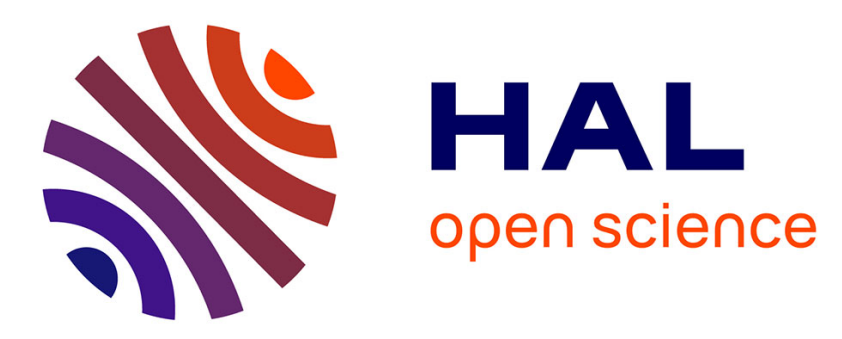

\title{
Bronchodilating effect of combined therapy with ipratropium bromide and ondansetron in patients with COPD
}

\author{
Romain Pauwels, Guy F. Joos, Charles Fogarty, Isidore Faiferman, Sandra \\ Hirschberg, Rupert Vessey, Emiel F.M. Wouters
}

\section{To cite this version:}

Romain Pauwels, Guy F. Joos, Charles Fogarty, Isidore Faiferman, Sandra Hirschberg, et al.. Bronchodilating effect of combined therapy with ipratropium bromide and ondansetron in patients with COPD. Pulmonary Pharmacology \& Therapeutics, 2008, 10.1016/j.pupt.2007.10.002 . hal-00499150

\author{
HAL Id: hal-00499150 \\ https://hal.science/hal-00499150
}

Submitted on 9 Jul 2010

HAL is a multi-disciplinary open access archive for the deposit and dissemination of scientific research documents, whether they are published or not. The documents may come from teaching and research institutions in France or abroad, or from public or private research centers.
L'archive ouverte pluridisciplinaire $\mathbf{H A L}$, est destinée au dépôt et à la diffusion de documents scientifiques de niveau recherche, publiés ou non, émanant des établissements d'enseignement et de recherche français ou étrangers, des laboratoires publics ou privés. 


\section{Author's Accepted Manuscript}

Bronchodilating effect of combined therapy with ipratropium bromide and ondansetron in patients with COPD

Romain Pauwels, Guy F. Joos, Charles Fogarty, Isidore Faiferman, Sandra Hirschberg, Rupert Vessey, Emiel F.M. Wouters

PII: $\quad$ S1094-5539(07)00094-6

DOI: $\quad$ doi:10.1016/j.pupt.2007.10.002

Reference: $\quad$ YPUPT 799

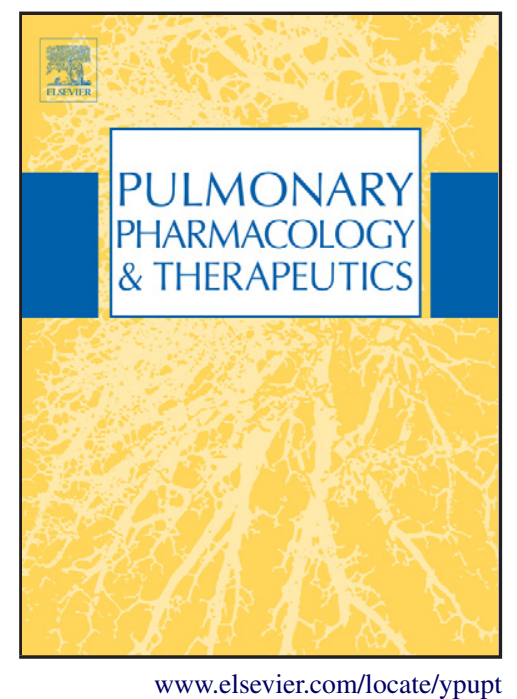

To appear in: $\quad$ Pulmonary Pharmacology \& Therapeutics

Received date: 18 August 2006

Revised date: $\quad 30$ September 2007

Accepted date: 6 October 2007

Cite this article as: Romain Pauwels, Guy F. Joos, Charles Fogarty, Isidore Faiferman, Sandra Hirschberg, Rupert Vessey and Emiel F.M. Wouters, Bronchodilating effect of combined therapy with ipratropium bromide and ondansetron in patients with COPD, Pulmonary Pharmacology \& Therapeutics (2007), doi:10.1016/j.pupt.2007.10.002

This is a PDF file of an unedited manuscript that has been accepted for publication. As a service to our customers we are providing this early version of the manuscript. The manuscript will undergo copyediting, typesetting, and review of the resulting galley proof before it is published in its final citable form. Please note that during the production process errors may be discovered which could affect the content, and all legal disclaimers that apply to the journal pertain. 


\section{Bronchodilating effect of combined therapy with ipratropium bromide and ondansetron in patients with COPD.}

Romain Pauwels, Guy F. Joos, Charles Fogarty, Isidore Faiferman, Sandra Hirschberg, Rupert Vessey, and Emiel F.M. Wouters.

Dr. Romain Pauwels\#, Dr. Guy F. Joos\#, Dr. Charles Fogarty, Spartanburg, North Carolina, USA, Dr.Sandra Hirschberg*, Dr. Isidore Faiferman*, Dr. Rupert Vessey, Dr. Emiel F.M. Wouters, Academic Hospital, Maastricht, The Netherlands.

\# Department of Respiratory Disease, Ghent University Hospital, Ghent, Belgium

* Glaxo Smith Kline Research and Development Ltd.

This study was funded by GlaxoSmithKline Pharmaceuticals.

Abstract

The objectives of this study were to determine the effect of single and repeat dosing with oral ondansetron, a 5-HT3-specific receptor blocker, on the degree and duration of bronchodilation induced by inhaled ipratropium bromide in patients with COPD. Five clinics and university medical centers in four countries participated in the study; forty seven patients with COPD were randomized to treatment; 44 completed all treatments. Patients had a baseline (pre-bronchodilator) FEV1 > 1 liter and post-bronchodilator (200 mcg salbutamol) FEV1 < $90 \%$ of predicted, with FEV1 reversibility (to $80 \mathrm{mcg}$ inhaled ipratropium bromide and $400 \mathrm{mcg}$ salbutamol) of at least $12 \%$ or $200 \mathrm{ml}$ over baseline. The study was divided into two parts. In Part A, each patient received in a random order, four-way cross-over manner, single doses of ondansetron placebo (oral) plus ipratropium bromide placebo (inhaled), ondansetron placebo plus ipratropium bromide $40 \mathrm{mcg}$ inhaled via MDI, ondansetron $24 \mathrm{mg}$ oral plus ipratropium bromide placebo and ondansetron $24 \mathrm{mg}$ plus ipratropium bromide $40 \mathrm{mcg}$. In Part B, each patient received in a random order, two-way crossover manner, ipratropium bromide $40 \mathrm{mcg}$ tid via MDI plus ondansetron $8 \mathrm{mg}$ oral, qid, for two days; on day 3 patients received a single dose of ipratropium bromide 40 mcg plus $8 \mathrm{mg}$ oral ondansetron. Alternatively, patients received ipratropium bromide via MDI and oral ondansetron placebo, as described above. Statistically significant differences in weighted mean FEV1 (0-6 hours), peak FEV1 and FEV1 determined 6 hours post-dose were noted comparing ipratropium bromide to placebo. Similar positive results were observed for sGaw and FVC. Addition of ondansetron to ipratropium bromide did not significantly modify values obtained with ipratropium alone. Ipratropium bromide induced a marked bronchodilation, compared to placebo. Addition of ondansetron (single or repeated doses) did not significanlty increase the degree or duration of 
bronchodilation induced by ipratropium alone. sGaw was consistently more sensitive than FEV1 in measuring extent and duration of bronchodilation.

Keywords: Drug combination, combination bronchodilator, COPD, bronchodilation, ondansetron, 5HT3, ipratropium bromide.

1. Introduction

COPD has been recognized as a major health problem for about 50 years (1). In contrast with other leading chronic diseases, its prevalence and disease-related morbidity and mortality are increasing (2-6). Bronchodilators are typically prescribed for maintenance therapy of the reversible obstructive component of the disease. In patients with minimally reversible or irreversible obstruction, symptom improvement observed following bronchodilator therapy may be related to the degree of reduction in gas trapping and dynamic hyperinflation, which, in turn, may result in reduction in the overall work of breathing $(7,8)$. The bronchodilators most commonly used are inhaled beta2adrenoceptor agonists and inhaled anticholinergics (2-5, 9); current international guidelines recommend combination therapy for patients not well controlled by monotherapy (2-6), since anticholinergics and beta2-adrenoceptor antagonists achieve their bronchodilating effects via different mechanisms (9). A number of studies have indeed demonstrated that, in patients with stable COPD, the combination is more effective than either agent alone (9-13).

Dominant autonomic control of the airways is provided by the parasympathetic nerves, which control a variety of airway functions $(14,15)$. Acetylcholine, released from the parasympathetic nerves, stimulates muscarinic receptors, causing bronchoconstriction and mucus secretion. The effect of acetylcholine in the airways is mediated mainly through three muscarinic receptor subtypes, designated M1, M2 and M3 (16). M1 receptors facilitate neurotransmission through the cholinergic ganglia; M2 receptors are found on pre and postganglionic parasympathetic nerves and inhibit release of acetylcholine, while $M 3$ receptors are present in airway smooth muscle (ASM) and submucosal glands and are responsible for mediating bronchoconstriction and mucus secretion $(16,17)$. Inhibition of acetylcholine release by M2 receptors may be decreased or lost due to M2 receptor dysfunction in asthma and in $\operatorname{COPD}(18,19)$, resulting in unopposed activity at the M3 receptors. This excessive M3 receptor stimulation may contribute to the bronchoconstriction and mucus hypersecretion observed in inflammatory airways diseases.

Serotonin (5-HT) has also been reported to have effects on airway smooth muscle contraction through interactions with multiple receptor subtypes. Most data has been generated in in vitro experiments. In isolated rat bronchi 5-HT induced contraction of airway smooth muscle (ASM) directly, by activating airway smooth muscle 5-HT2 receptors, and indirectly, by activating 5-HT2 receptors on parasympathetic nerve endings, leading to release of acetylcholine $(20,21)$. 
Studies in human airways have shown that cholinergic contraction induced in vitro following electrical stimulation was increased by the presence of $5-\mathrm{HT}$; this facilitation of cholinergic contraction could be blocked completely by tropisetron, a 5-HT3 and 5-HT4 receptor blocker, and partially by ondansetron, a 5-HT3 receptor blocker (22). In subjects with asthma, plasma levels of $5 \mathrm{HT}$ are elevated and correlate with clinical severity rating and FEV1 (23). One possible source of $5-\mathrm{HT}$ are the endocrine cells of the lung (24); an increase in the number of endocrine cells (and presumably $5-\mathrm{HT}$ ) has been described in bronchiectatic lungs, lung containing neoplasms and lungs of subjects exposed to hypoxia (25). In a small group of subjects with COPD reversible to albuterol, administration of inhaled or of intravenous ketanserin, a 5-HT2 antagonist, induced a small degree of bronchodilation that was statistically significantly different from placebo, 30 minutes following administration of the drug (26). Combination therapy has become standard in the treatment of airway disease; this allows the targeting of diverse mechanisms that participate in the disease process. Identification and characterization of these mechanisms utilizing specific inhibitors may improve our understanding of the disease and could help in the development of optimal treatment. The objective of this study was to determine the short term effect of single and repeat dosing with ondansetron, a 5-HT3- specific receptor blocker, on the degree of bronchodilation induced by inhaled ipratropium bromide in patients with stable COPD. Three endpoints were evaluated in the determination of bronchodilation: FEV1 and FVC, measured by spirometry, and sGaw, determined by plethysmography.

\section{Materials and Methods}

\subsection{Study Design}

This was a double-blind, randomized, placebo controlled, crossover, two part study comparing the effect on pulmonary function of inhaled ipratropium bromide (Atrovent $®$, Boehringer Ingelheim, 27), 40 mcg (single dose or tid), given by metered-dose inhaler, ondansetron (Zofran ${ }^{\circledR}$, GlaxoSmithKline, 28), $24 \mathrm{mg}$ single dose or $8 \mathrm{mg}$ tid, given orally, and their combination.

The study was carried out in five centers in four countries (2 centers in the US, one center each in Belgium, The Netherlands and Germany). The study was approved by the appropriate Ethics Committee/Institutional Review Board at each site and was conducted according to the principles of good clinical practice.

The study was divided into two parts and a screening visit. At screening, baseline measurements were performed and the eligibility of patients to participate in the study was determined. Part A of the study (four-way crossover) was conducted within 2 weeks of the screening visit; patients were randomized to receive, in a cross-over manner, single doses of ondansetron placebo plus ipratropium bromide placebo, ondansetron placebo plus ipratropium bromide 40 mcg via MDI, ondansetron $24 \mathrm{mg}$ oral plus ipratropium placebo, and ondansetron $24 \mathrm{mg}$ oral plus ipratropium 
bromide $40 \mathrm{mcg}$ via MDI. Patients received single doses of each study medication in the clinic; spirometry and plethysmography were performed 30 minutes before and 0.5, 1, 2, 3, 5 and 6 hours following administration of study medication. Dosing days were separated from each other by at least 48 hours.

Part B of the study was conducted at least 48 hours following the last administration of study medication in Part A. Part B was a randomized, double-blind, placebo-controlled, two-period crossover study. Patients were randomized to receive ipratropium bromide $40 \mathrm{mcg}$ tid via MDI plus ondansetron placebo qid for two days; on day 3 patients received a single dose of ipratropium bromide $40 \mathrm{mcg}$ via MDI plus ondansetron placebo. Alternatively, patients received ipratropium bromide $40 \mathrm{mcg}$ tid via MDI plus ondansetron $8 \mathrm{mg}$ qid orally, for two days; on day 3 patients received a single dose of ipratropium bromide $40 \mathrm{mcg}$ via MDI plus ondansetron $8 \mathrm{mg}$ orally. The two study periods were separated from each other by at least 48 hours. Patients remained in the clinic for about 7 hours following administration of study medication on day 3 of each crossover period; spirometry and plethysmography were determined as before, 30 minutes prior to and $0.5,1$, 2, 3, 5 and 6 hours following administration of study medication, on day 3 of each crossover period. A follow-up visit was conducted 7 to 14 days after the last dosing with study medication.

\subsection{Patients}

Inclusion criteria included the following: male and female patients, age $\geq 40$ to $\leq 75$ years old, who gave written informed consent, with a diagnosis of COPD according to the American Thoracic Society guidelines (2); current or former (discontinued smoking for $>1 \mathrm{yr}$ ) smokers (smoking history $\geq 10$ packs/year); pre-bronchodilator FEV1 > 1 liter, post-bronchodilator (180 mcg albuterol/200 mcg salbutamol via MDI) FEV1 < 90\% of predicted; FEV1/FVC < 0.7; an increase in FEV1 of at least $12 \%$ or $200 \mathrm{ml}$ over baseline after $80 \mathrm{mcg}$ inhaled ipratropium bromide and 360 $\mathrm{mcg}$ albuterol/400 mcg salbutamol. Entry criteria are similar to those of other publications $(13,29$, $30,31,32$ ) except that only one (29) included a reversibility criterion for entry (an increase in FEV1 of $15 \%$ over baseline following bronchodilator). The other studies did not include a reversibility requirement; on the other hand, in all studies FEV1 increased by $200 \mathrm{~mL}$ or more over baseline following the administration of a single dose of bronchodilator. 
Exclusion criteria included: a diagnosis of asthma; an acute COPD exacerbation that required treatment with oral corticosteroids or hospitalization, or upper respiratory tract infection, within one month of screening; need for short or long-term oxygen therapy; use of oral corticosteroids at doses > $10 \mathrm{mg} /$ day; change in the dose of inhaled or oral corticosteroids within 6 weeks of screening.

\subsection{Efficacy parameters}

The primary efficacy variable was the weighted mean FEV1 (0-6 hours) for single doses or the last dose of the repeat-dose period. Secondary efficacy variables were weighted mean sGaw (0-6 hr), peak values for FEV1, FVC, FEV1/FVC ratio and sGaw (peak refers to the maximum value in 0-6 hours), and FEV1, FVC, FEV1/FVC ratio and sGaw determined 6 hours post-dosing. Spirometry and plethysmography were performed following standard procedures $(3,4,5)$. Pulmonary function determinations were performed at the same time of day in order to minimize daytime variability of measurements. Rescue inhalations with short-acting bronchodilator were to be avoided for at least 4 hours prior to dosing to at least 6 hours post-dosing. Subjects abstained from long-acting beta2agonists, long-acting anticholinergics (tiotropium) and xanthines for two weeks prior to the first dose to the end of the study.

\subsection{Safety variables}

Safety was assessed using adverse event reporting, electrocardiograms, vital signs and clinical laboratory evaluations.

\subsection{Statistical Analysis}

The primary comparison of interest was weighted mean FEV1 (0-6 hours) in the single dose crossover phase, comparing ondansetron (24mg) and ipratropium (40mcg) vs. ipratropium (40mcg) and ondansetron placebo. This comparison was repeated for weighted mean sGaw (0-6 hours); peak FEV1, FVC, FEV1/FVC ratio and sGaw and for FEV1, FVC, FEV1/FVC ratio and sGaw determined 6 hours post-dosing. 
Unless otherwise specified, all analyses were performed using SAS software (version 8.2). This was a multicentre study; for the purpose of this study, centre and/or country differences were not assessed due to the small number of centres in each country and the small number of patients at each site.

Actual sample times were used to calculate the weighted means and peak endpoints. The weighted mean parameters were calculated by dividing the area under the curve (AUC) by time. The AUC was calculated using the linear trapezoidal method.

In order to evaluate the primary outcome (weighted mean FEV1 0-6 hours) a mixed effects model was fitted, with fixed effects for period, treatment and baseline FEV1 (as a covariant) and random effects for subjects. Baseline FEV1 was fitted as a continuous variable; baseline FEV1 was the pre-dose value of FEV1 on the appropriate dosing day (Study Part A-single dose). Least square (LS) means for each treatment, differences in LS means and the 95\% confidence intervals for the difference are presented. The same model was used to evaluate this outcome for Part B of the study (repeat dose) using baseline as the pre-dose value of FEV1 on Day 1. sGaw data was log transformed for analysis., treatment ratios were calculated by taking the difference between least square means and the $95 \%$ confidence interval was calculated for the difference and anti-logged.

Information from previous studies comparing ipratropium plus beta2-agonist vs ipratropium , following administration of bronchodilator $(10,13)$ has provided estimates of within subject standard deviation for weighted mean FEV1 of $0.15 \mathrm{~L}$ and shown differences of $0.06 \mathrm{~L}$ and $0.08 \mathrm{~L}$. In order to power the study based on these differences, a sample of more than 60 subjects would have been required. Due to logistics and resources, the subject number was limited to 40: with 40 subjects completing and a within subject standard deviation of $0.15 \mathrm{~L}$, differences in FEV1 weighted means of $0.096 \mathrm{~L}$ and $0.111 \mathrm{~L}$ can be detected with $80 \%$ and $90 \%$ power, respectively. All calculations were 2-sided and assumed a significance level of $5 \%$.

\section{Results}

Forty seven patients were randomized to treatment; forty four completed all treatments and three were discontinued prematurely. One patient was withdrawn because of a protocol violation, after undergoing all single-dose treatments and one repeat-dose treatment; one patient withdrew consent after receiving one single-dose treatment (placebo), and one patient was withdrawn because of lack of compliance with the protocol, after receiving all single-dose treatments.

A summary of demographic and baseline data is presented in Table 1. Following administration of bronchodilator, 45 patients had an increase in FEV1 of $>200 \mathrm{~mL}$ and two had an increase of 200 $\mathrm{mL}$, while 17 patients had increases of $>12 \%$ over baseline. There were no differences in the responses to bronchodilator between all patients and those taking corticosteroids. Concomitant 
medications at baseline included the following bronchodilators: salbutamol/albuterol (43\% of patients), ipratropium bromide (17\%), the combination of ipratropium bromide and albuterol, Combivent ${ }^{\circledR}(6 \%) .38 .2 \%$ of the patients were on inhaled corticosteroids and $2 \%$ on oral corticosteroids (7.5 mg/day). The bronchodilator reversibility as percent increase from baseline was $25.0 \%$ (mean value, range from 6.1 to $50.0 \%$ ). Xanthines, inhaled long-acting beta2-agonists, and tiotropium bromide were discontinued two weeks before administration of the first dose of study medication and for the duration of the study.

The combination of ipratropium and ondansetron appeared to be well tolerated. There were no withdrawals due to adverse experiences. A statistically significant difference in weighted mean $\mathrm{FEV}_{1}(0-6$ hours) between treatments was noted in the comparison of ipratropium bromide vs placebo (Tables 2, 3, Figure 1). Treatment with ipratropium bromide (compared to placebo) also resulted in a statistically significant increase in peak FEV1 and in FEV1 determined 6 hours postdose (Table 4). However, dosing with ondansetron and ipratropium together was no more effective than dosing with placebo and ipratropium bromide in increasing the weighted mean of FEV1 (0-6 hours), peak FEV1 and FEV1 $6 \mathrm{hr}$. This was observed for both the single dose and the repeat-dose parts of the study.

Similarly, statistically significant increases in weighted mean sGaw, and in peak values and values determined 6 hours post-dosing for FVC and sGaw were observed after dosing with ipratropium, compared to placebo. As was observed for FEV1, there was no significant increase in FVC and sGaw after dosing with both ipratropium and ondansetron compared with ipratropium alone.

Results for the repeat-dose part of the study were similar to results from single dose administration (Table 4, Figure 2).

The only statistically significant change observed after dosing with ondansetron was an increase in FVC 6 hours post-dosing with a single $24 \mathrm{mg}$ dose, in the presence of ipratropium placebo. When compared with ondansetron placebo/ ipratropium placebo, this treatment resulted in a statistically significant increase in FVC $6 \mathrm{~h}$ of $0.132 \mathrm{~L}$ (95\% confidence interval: $0.021,0.242 \mathrm{~L})$. This increase was similar to that seen with ipratropium $40 \mathrm{mcg}$ compared with placebo (treatment difference $0.224 \mathrm{~L} ; 95 \%$ confidence interval: $0.113,0.335 \mathrm{~L}$ ). Following co-administration of ondansetron 24 mg and ipratropium $40 \mathrm{mcg}$, FVC was not significantly different to FVC after administration of ipratropium $40 \mathrm{mcg}$ alone. In order to compare changes in sGaw and FEV1, effect size was calculated by dividing treatment differences by the standard deviation; sGaw was consistently more sensitive than FEV1, particularly at peak value and 6 hours post-dose (Table 5).

\section{Discussion}

The comparison of ipratropium bromide $40 \mathrm{mcg}+$ ondansetron $24 \mathrm{mg}$ with ipratropium bromide 40 mcg + placebo showed that there was no improvement in weighted mean FEV1 (0-6 hours), peak FEV1 or FEV1 determined 6 hours post-dosing when patients received ondansetron, compared 
with placebo. Similar lack of improvement was observed for FVC, FEV1/FVC ratio and sGaw. Therefore, results of this randomized, double-blind, placebo-controlled, crossover study indicate that dosing with oral ondansetron in addition to ipratroprium is not effective in improving pulmonary function in patients with COPD.

When ipratropium bromide was compared with placebo, statistically significant increases in weighted mean FEV1 (0-6 hours), peak FEV1 and FEV1 6 hours were observed. Similar positive results were determined for FVC and sGaw. The comparison of ondansetron $24 \mathrm{mg}$ with placebo showed a statistically significant improvement in FVC determined 6 hours post-dosing, but no other variable showed a statistically significant change. Results obtained from a limited repeat-dose administration were similar to those observed following single doses. However since we have not corrected for multiple comparisons, this increase could be a false-positive finding.

As expected, ipratropium bromide induced a marked bronchodilation compared to placebo, as determined by spirometry (FEV1). This was accompanied by increases in sGaw (weighted mean, peak value and sGaw determined 6 hours post-dose); sGaw was consistently more sensitive than FEV1, particularly in determinations at peak and 6 hours post-dose. Similar results have been observed with ipratropium bromide (12) and other bronchodilators $(29,33)$ in patients with COPD $(12,29)$ and in normal healthy volunteers (33). In a recent publication, spirometry, plethysmography and impulse oscillometry were compared in their ability to measure bronchodilation induced by inhalation of increasing doses of salbutamol in patients with COPD. For the lower doses of salbutamol, plethysmography (sGaw) and impulse oscillometry were more sensitive than FEV1 in detecting bronchodilation; on the other hand, sGaw was the most variable measurement, followed by oscillometry parameters, with spirometry (FEV1) being the least variable (34). Plethysmography measures airway resistance, conductance and lung volumes while impulse oscillometry measures airway resistance and lung reactance (35). Unlike spirometry, these tests do not require effort dependent forced expiration. In patients with COPD experiencing bronchodilation induced by increasing doses of salbutamol, the shape of the dose-response curves was different for sGaw compared to other measurements; there was an initial sharp improvement in sGaw at low doses of salbutamol, after which the gradient of the curve was similar to other readings (34). This intial rapid improvement in airway conductance may explain the increased sensitivity of plethysmography compared with the other methods at low bronchodilator doses. For the purposes of detecting small physiological effects in COPD (34) or asthma (36), this may be a potential advantage (e.g. measuring physiological changes at 12 or 24 hours after administration of a bronchodilator .

Serotonin $(5-\mathrm{HT})$ has been reported to have effects on airway smooth muscle contraction through interactions with multiple receptor subtypes. Conversely, blockers of 5-HT receptor subtypes have been shown to reduce constriction or induce bronchodilation. In in vitro studies in human airways, tropisetron, a 5-HT3 and 5-HT4 receptor blocker, and ondansetron, a 5-HT3 receptor blocker, were able to completely or partially, respectively, reduce the facilitation of contraction induced by 
electrical stimulation in the presence of 5-HT (22). In a small group of subjects with COPD reversible to albuterol, administration of inhaled or of intravenous ketanserin, a 5-HT2 antagonist, induced a small degree of bronchodilation that was statistically significantly different from placebo (26). In contrast, in this study, addition of a 5HT3 receptor blocker (ondansetron) did not improve the effect of ipratropium in inducing bronchodilation in patients with COPD.

In conclusion, results obtained in this study suggest that the participation of serotonin in establishing pulmonary tone or inducing bronchoconstriction may be mediated through interaction with 5-HT subtype receptors other than 5-HT3. In vitro data suggests that blocking several 5-HT receptors (5-HT3 and 5-HT4; 22) may have been more effective than blocking a single type of receptor. This suggests that tropisetron may have been a better choice than ondansetron. In addition, although both compounds have a high 5-HT3 binding affinity, tropisetron has a considerably longer half life than ondansetron (8-10 hrs and $3.5 \mathrm{hrs}$, respectively) (36). On the other hand, one goal of this study was to identify receptors involved in the disease process; this required specific receptor blockers. As additional mechanisms involved in airway diseases are identified and the number of drugs used in treatment increases, this type of study, conducted in a small number of patients for a short period of time, may be of value in the identification of useful drug combinations $(38,39)$. This study also suggests that determination of sGaw may be a useful complement to the determination of FEV1 in establishing both peak bronchodilatory activity and duration of effect.

ACKNOWLEDGMENT : We thank Sheng-Fang Su, MS, of GlaxoSmithKline Research and Development, Ltd., for her contribution to this study. We also thank Vanessa Schelfhout, MD, Ghent University Hospital, Ghent, Belgium and Bruno Dietrich, MD, Clinical Research, Hennigsdorf , Germany for their help in the realisation of this study 


\section{References}

[1] Senior RM, Anthonisen NR. Chronic Obstructive Pulmonary Disease (COPD) Am J Respir Crit Care Med. 1998; 157: 139-147

[2] American Thoracic Society. Standard for the diagnosis and care of patients with Chronic Obstructive Pulmonary Disease. Am J Respir Crit Care Med. 1995; 152: 77-120.

[3] Siafakas NM, Vermeire P, Pride NB et al. Optimal assessment and management of chronic obstructive pulmonary disease (COPD). Eur Respir J,. 1995; 8: 1398-1420.

[4] British Thoracic Society. BTS guidelines for the management of chronic obstructive pulmonary disease. Thorax 1997; 52 (suppl. 5) S1-S28.

[5] Global Initiative for Chronic Obstructive Lung Disease. Global strategy for the diagnosis, management and prevention of Chronic Obstructive Lung Disease. NHLBI/WHO workshop report. Bethesda National Heart, Lung and Blood Institute, April 2001; Update of the Management Sections, GOLD website (www.goldcopd.com)

[6] Fabbri LM, Hurd SS, for the GOLD Scientific Committee. Global strategy for the diagnosis, management and prevention of COPD: 2003 update. Eur Respir J. 2003; 22: 1-2.

[7] O'Donnell DE, Webb KA. Exertional breathlessness in patients with chronic airflow limitation: the role of hyperinflation. Am Rev Respir Dis. 1993; 148: 1351-1357.

[8] Calverley $P$, Bellamy $D$. The challenge of providing better care for patients with chronic obstructive pulmonary disease: the poor relation of airway obstruction? Thorax 2000; 55 : 78-82

[9] Rennard SI. Combination bronchodilator therapy in COPD. Chest 1995, 107 (suppl) 17511755

[10] Combivent Inhalation Aerosol Study Group. In chronic obstructive pulmonary disease, a combination of ipratropium bromide and albuterol is more effective than either agent alone. Chest 1994; 105: 1411-1419.

[11] Ikeda A, Nishimura K, Koyama $\mathrm{H}$ et al. Bronchodilating effects of combined therapy with clinical dosages of ipratropium bromide and salbutamol for patients with COPD: comparison with ipratropium bromide alone. Chest 1995; 107: 401-405 
[12] van Noord JA, de Munck DRAJ, Bantje Th A et al. Long-term treatment of chronic obstructive pulmonary disease with salmeterol and the additive effect of ipratropium bromide. Eur Respir J. 2000; 15: 878-885.

[13] Sichletidis L, Kostakis J, Marcou S et al. Bronchodilatory responses to formoterol, ipratropium bromide and their combination in patients with COPD. Int J Clin Pract. 1999; 53: 185-188.

[14] Boushey H A. Role of the vagus nerves in bronchoconstriction in humans. 1985, Chest, 5 : 197S-201S

[15] Nadel J and Barnes P. Autonomic regulation of the airways. 1984, Ann Rev Med 35: 451467.

[16] Ramnarine S, Haddad E, Khawaja A, Mak J and Rogers D. On muscarinic control of neurogenic mucus secretion in ferret trachea. 1996, J Physiol (London), 494: 577-586

[17] van Nieuwstadt R, Henricks $P$, Hajer R et al. Characterization of muscarinic receptors in equine tracheal smooth muscle in vitro. 1997, Veterinary Quarterly, 19: 54-57.

[18] Schultheis A, Bassett D and Fryer A. Ozone-induced airway hyperresponsiveness and loss of neuronal M2 muscarinic receptor function. 1994, J Appl Physiol, 76: 1088-1097.

[19] Jacoby DB, Gleich GJ and Fryer A. Human eosinophil major basic protein is an endogeous allosteric antagonist at the inhibitory muscarinic M2 receptor. 1993, J Clin Invest, 91: 1314-1318.

[20] Szarek JL, Zhang JZ and Gruetter CA. Mechanisms of 5-Hydroxytryptamine-induced contraction of isolated rat intrapulmonary bronchi. 1995, Pulm Pharmacol, 8: 273-281

[21] Germonpre PR, Joos GF and Pauwels RA. Modulation by 5- $\mathrm{HT}_{1 \mathrm{~A}}$ receptors of the 5- $\mathrm{HT}_{2}$ receptor-mediated tachykinin-induced contraction of the rat trachea in vitro. Brit. J. Pharmacol. 1998, 123: 1571-1578

[22] Dupont LJ, Pype JL, Demedts MG, De Leyn P, Deneffe G and Verleden GM. The effects of 5HT on cholinergic contraction in human airways in vitro. 1999, Eur. Respir. J. 14: 642-649.

[23] Lechin F, van der Dijs B, Orozco B, Lechin M and Lechin AE. Increased levels of free serotonin in plasma of symptomatic asthmatic patients, 1966, Ann Allergy Asthma Immunol. 77: 245-253. 
[24] Gosney JR, Sissons MCJ, Allibone RO et al. Pulmonary endocrine cells in chronic bronchitis and emphysema. 1989, J Pathol. 157: 127-133

[25] Gould VE, Linnoila I, Memoli VA et al. Neuroendocrine components of the bronchopulmonary tract: hyperplasias, dysplasias and neoplasms. Lab Invest. 1983, 49: 519-537

[26] Cazzola M, Guidetti E, Sepe J et al. Acute respiratory and cardiovascular effects of inhaled ketanserin in COPD. A comparative study with intravenously administered ketanserin. Chest, 1990, 97: 901-905.

[27] Atrovent Inhaler. Patient information leaflet. Boehringer Ingelheim, 2000.

[28] Zofran Tablets. Patients information leaflet. GlaxoSmithKline, 2002.

[29] Maesen FPV, Smeets JJ, Costongs MAL et al. Ba 679, a new long-acting antimuscarinic bronchodilator: a pilot dose-escalation study in COPD. Eur Respir J. 1993; 6: 1031-1036.

[30] Briggs DD Jr, Covelli H, Lapidus R et al. Improved daily efficacy of tiotropium compared with salmeterol in patients with COPD. Pulm Pharmacol \& Ther 2005; 18: 397-404.

[31] Littner MR, llowite JS, Tashkin DP et al. Long-acting bronchodilation with once-daily dosing of tiotropium (Spiriva) in stable chronic obstructive pulmonary disease. Am J Respir Crit Care Med. 2000; 161: 1136-1142.

[32] Van Noord JA, Bantje Th A, Eland ME et al. A randomized controlled comparison of tiotropium and ipratropium in the treatment of chronic obstructive pulmonary disease. Thorax 2000; 55: 289294.

[33] Morice AH, Waterhouse JC, Peers EM, Parry-Billings M. Use of whole-body plethysmography to compare bronchodilator inhaler efficacy. Respiration 1998, 65: 120-124

[34] Borrill ZL, Houghton CM, Woodcock AA et al. Measuring bronchodilation in COPD trials. Brit J Clin Pharmacol 2004; 59: 379-384

[35] Goldman MD Clinical applications of forced oscillation. Pulm Pharmacol \& Ther 2001; 14 : $341-350$

[36] Houghton CM, Woodcock AS \& Singh D. A comparison of lung function methods for assessing dose-response effects of salbutamol. Brit J Clin Pharmacol. 2004; 58: 134-141. 
[37] Wolf $\mathrm{H}$. Preclinical and clinical pharmacology of the 5-HT3 receptor antagonists. Scand J Rheumatol 2000 Suppl 113:37-45

[38] Tonelli, M, Zingoni M, Bacci E et al. Short-term effect of the addition of leukotriene receptor antagonists to the current therapy in severe asthnmatics. Puklm Pharmacol Ther 2003; 16: 237 240 .

[39] Vatrella A, Ponticiello A, Pelaia G et al. Bronchodilating effects of salmeterol, theophylline and their combination in patients with moderate to severe asthma. Pulm Pharmacol Ther 2005; 18: 89-

92. 
Table 1.

Summary of Demographic and Baseline Data of ITT Population $(n=47)$

Variables Data

Age, yr; mean (SD), range

$59.6(7.8), 43-75$

Sex, No. (\%)

male

$42(89)$

female

$5(11)$

Race, No. (\%)

White

$42(89)$

Black

$4(9)$

American-Hispanic

$1(2)$

Concomitant Medications

Inhaled corticosteroids

$18(38.2 \%)$

Oral Corticosteroids

$1(2 \%)$

$\mathrm{FEV}_{1}$ before albuterol/salbutamol (all patients), L

$1.70(0.49)$

FEV1 before albuterol/salbutamol, L(patients taking corticosteroids)

$1.72(0.53)$

FEV1 before albuterol/salbutamol, \% Predicted (all patients)

$49.0(12.1)$

FEV1 after albuterol/salbutamol (all patients), L

$2.09(0.52)$

FEV1 after albuterol/salbutamol (patients taking corticosteroids), L

$2.1(0.51)$

Reversibility

Delta FEV1: increase over baseline (all patients), L

$0.39(0.17)$

Delta FEV1; increase over baseline (patients taking corticosteroids), L

$0.38(0.11)$

Delta FEV1; \% increase over baseline (all patients)

$25.0(12.1)$

Delta FEV1: percent of predicted value (all patients)

$11.3(4.6)$ 
Table 2

Summary of derived parameters: Weighted Mean 0-6 h FEV1 (L)

\begin{tabular}{|c|c|c|c|}
\hline Treatment & $\mathrm{N} n$ & Mean (SD) & Aedian (range) \\
\hline Single dose (Part A) & & & \\
\hline Ondansetron pbo + ipratropium pbo & 4747 & $1.683(0.4995)$ & $1.608(0.75-2.96)$ \\
\hline Ondansetron pbo + ipratropium 40 mcg & 4646 & $1.849(0.5243)$ & $1.794(0.843 .18)$ \\
\hline Ondansetron $24 \mathrm{mg}+$ ipratropium pbo & 4646 & $1.702(0.5141)$ & 1.65 \\
\hline $\begin{array}{l}\text { Ondansetron } 24 \text { mg + ipratropium } 40 \text { mcg } \\
\text { Repeat dose (Part B) }\end{array}$ & 4646 & $1.858(0.5288)$ & 3) \\
\hline Ipratropium 40 mcg qid + Ondansetron pbo tid & 4544 & $1.795(0.5245)$ & $1.725(0.75-3.11)$ \\
\hline Ipratropium $40 \mathrm{mcg}$ qid + ondansetron $8 \mathrm{mg}$ tid & 4543 & $1.761(0.5168)$ & 1.6 \\
\hline
\end{tabular}


Table 3

Summary of Results for Weighted Mean 0 - 6 h FEV $_{1}(\mathrm{~L})$ - Single Dose Difference Between Combinations of Study Medications

Treatment Comparison

Ondansetron $24 \mathrm{mg}+$ ipratropium $40 \mathrm{mcg}$ vs 0.001

Ondansetron pbo + ipratropium $40 \mathrm{mcg}$

Ondansetron $24 \mathrm{mg}+$ ipratropium pbo vs

Ondansetron pbo + ipratropium pbo

Ondansetron pbo + ipratropium $40 \mathrm{mcg}$ vs

Ondansetron pbo + ipratropium pbo
$0.011 \quad-0.033,0.055$

$0.149 \quad 0.105,0.194$
$-0.044,0.046$ 
Table 4

Summary of Results for FEV1, FVC and sGaw.

Ipratropium Bromide vs Placebo - Single Dose

Differences of Least Square Means for FEV1 and FVC

Variable Least Square Means

Test - Reference Treatment

Test Reference Difference $95 \% \mathrm{Cl}$

Treatment Treatment

Weighted Mean

1.84

1.69

0.149

$(0.105,0.194)$

FEV1 0-6 hr.

\begin{tabular}{|c|c|c|c|c|}
\hline Peak FEV1, L & 1.98 & 1.80 & 0.173 & $(0.123,0.223)$ \\
\hline FEV1 6 hr post-dose & 1.73 & 1.65 & 0.078 & $(0.017,0.138)$ \\
\hline Peak FVC, L & 3.70 & 3.38 & 0.324 & $(0.228,0.420)$ \\
\hline FVC 6 hr post-dose & 3.29 & 3.07 & 0.224 & $(0.113,0.335)$ \\
\hline & Ipratr & Bromide vs & $\mathrm{bo}-\mathrm{Si}$ & \\
\hline & Ratio & metric Lea & are Mea & \\
\hline Variable & metric & & Ratio & ic Means \\
\hline Squ & are $\mathrm{Me}$ & & Test / & Treatment \\
\hline Tes & & Reference & Ratio & $95 \% \mathrm{Cl}$ \\
\hline Tre & ment & Treatment & & \\
\hline Weighted Mean & 0.574 & 0.420 & 1.368 & $(1.179,1.588)$ \\
\hline sGaw 0-6 hr. & & & & \\
\hline Peak sGaw & 0.721 & 0.493 & 1.463 & $(1.265,1.692)$ \\
\hline sGaw 6 hr post-dose & 0.454 & 0.383 & 1.184 & $(1.008,1.392)$ \\
\hline
\end{tabular}


Table 5

Treatment effect (Treatment Difference / Standard Deviation) - Single Dose

Parameter

effect size

(treatment difference/ standard deviation)

1) FEV1 wm (0-6h)

1.400

$(0.149 / 0.1064)$

2)FEV1 peak (0-6h)

1.455

0.054

$(0.173 / 0.1189)$

4)sGaw wm(0-6h)

1.436

$(0.078 / 0.1447)$

5)sGaw peak (0-6h)

1.786

$(0.313 / 0.2182)$

6)sGaw $6 \mathrm{~h}$

0.717

$(0.381 / 0.2130)$

$(0.169 / 0.2361)$

The effect size is equal to the treatment difference divided by the standard deviation; treatment differences for sGaw are on the log scale.

wm=weighted mean 
Figure 1

Weighted mean FEV1 determined for six hours following single-dose administration

Figure 2

Geometric mean sGaw determined for six hours following single-dose administration 


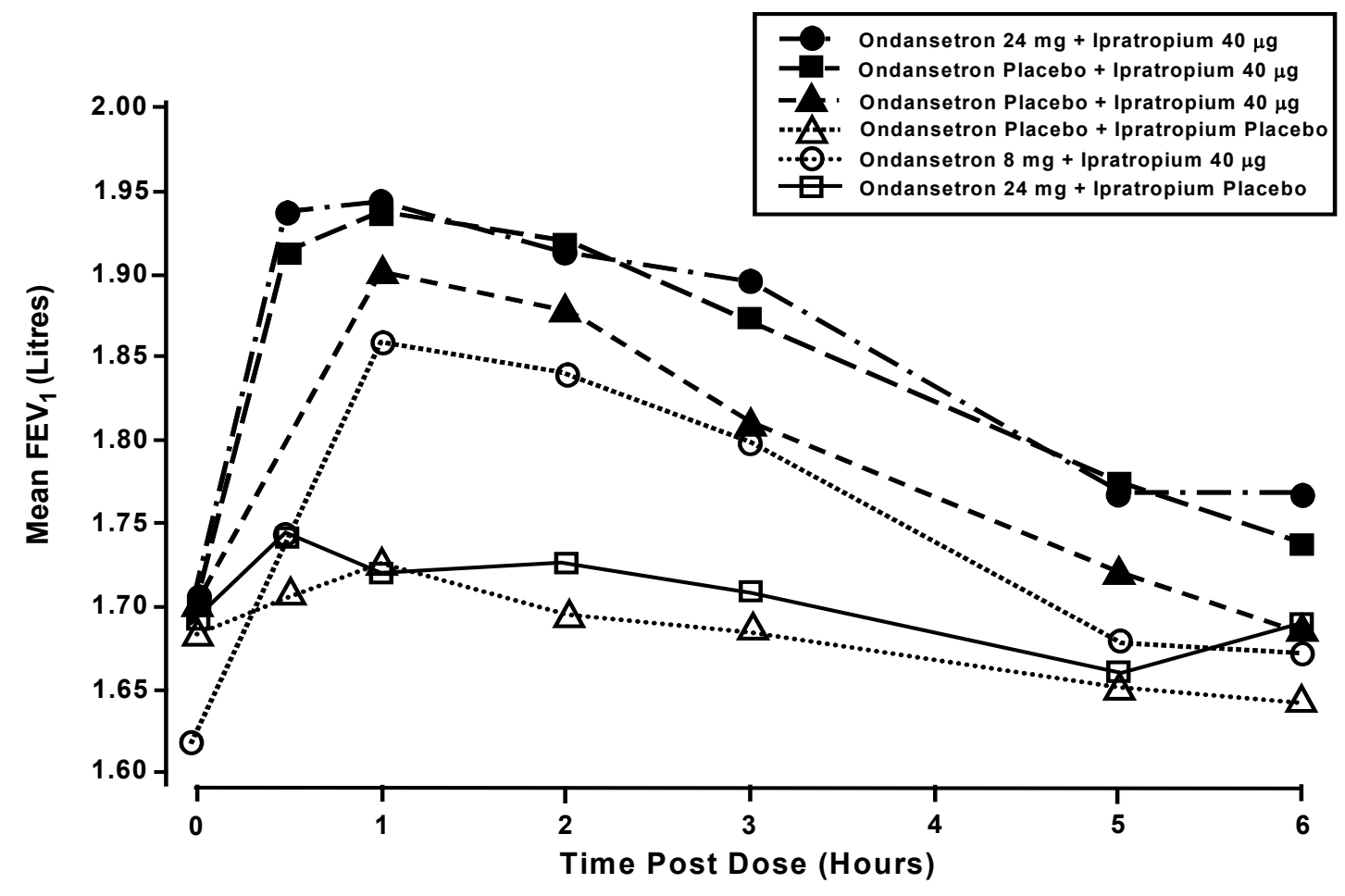

\section{Figure 2. Geometric mean sGaw determined for six hours following single and last} dose (of the repeat dose, $\Delta \circ$ ) administration.

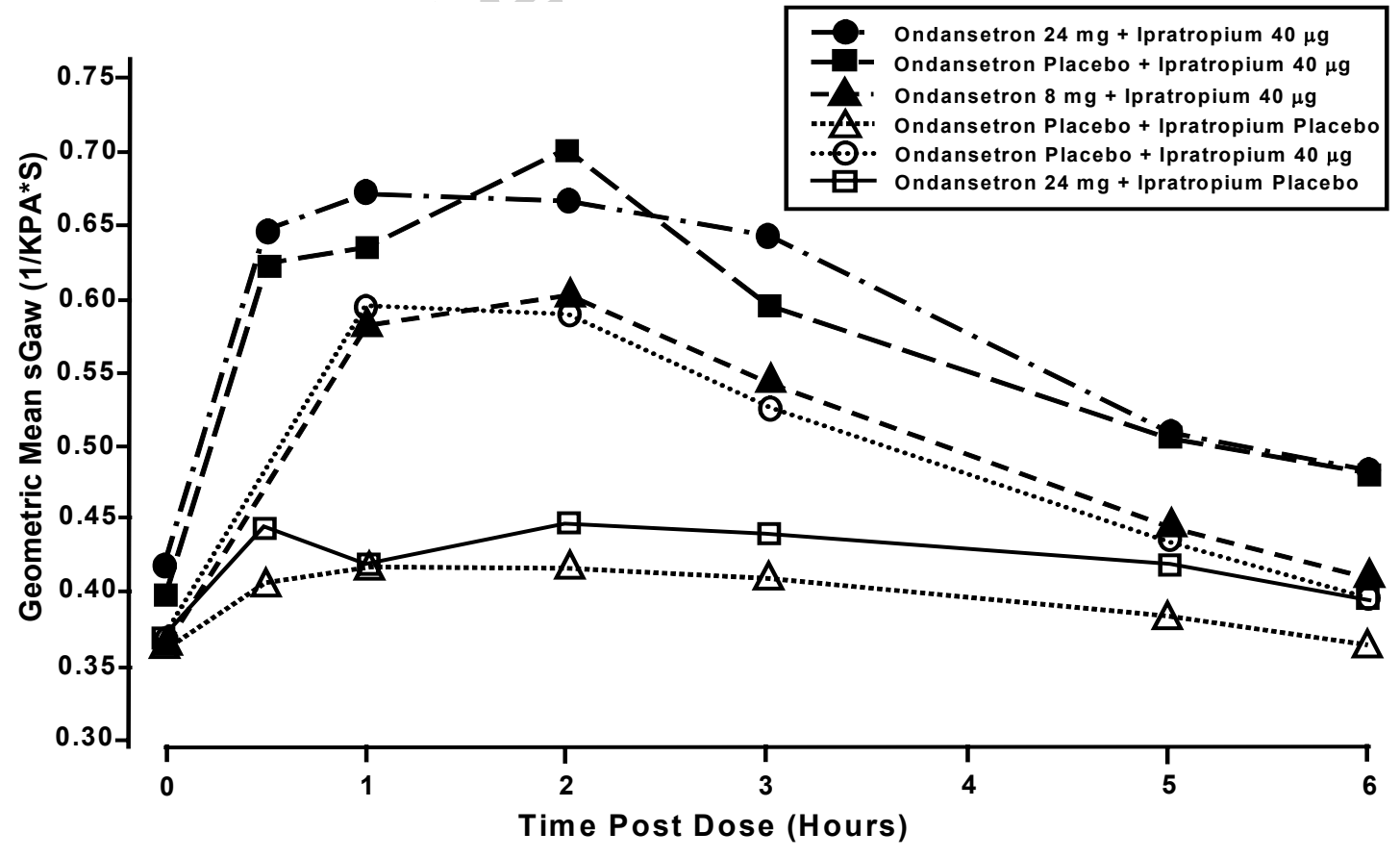

